\title{
Vaccination Hesitancy, Knowledge and the Role of Confidence
}

\author{
Jens Oliver Krüger (University of Koblenz) and Kathrin Krüger (Independent \\ Scholar)
}

\begin{abstract}
:
While from a medical point of view it seems obvious that "vaccination is one of the most effective ways to prevent disease" (World Health Organization [WHO], 2020), some people reject vaccinations for various reasons. The scientific discourse refers to them as vaccination hesitant. In this article we take a closer look at the different concepts of knowledge underlying vaccination hesitancy. We look at the history of vaccination hesitancy, examine current studies and report on select, empirical research into parental vaccination hesitancy, that we carried out in 2014/2015. Finally, we argue that the key challenge in vaccination education is not only to provide information but to build confidence.
\end{abstract}

Keywords:

anti-vaccination movement; confidence; knowledge; parenting; vaccination hesitancy

In the wake of the COVID-19 pandemic, social sensitivity and interest in immunological issues has increased considerably. People around the world are eagerly awaiting the development of a vaccine that could enable the easing of restrictions imposed on public life. At the same time, opponents of vaccination publicly demonstrate their opposition to vaccinations alongside conspiracy theorists.

While from a medical point of view it seems obvious that "vaccination is one of the most effective ways to prevent disease" (WHO, 2020), some people reject vaccinations for various reasons. This is a problem, because the community is dependent upon the highest possible percentage of immunized individuals to guarantee so-called "herd immunity", which is important in protecting those people who cannot protect themselves with a vaccination. This is one of the reasons why the WHO declared "vaccine hesitancy" as being one of the ten greatest global health threats in 2019 (WHO, 2019).

But what exactly is meant by vaccine hesitancy? While it has been argued that the definition given by the WHO - the "reluctance or refusal to vaccinate despite the availability of vaccines" (WHO, 2019) - may not be precise enough (Bedford et al., 2018) and that it is useful to differentiate between a behavioural and a more psychological definition (Betsch et al., 2018), in this article we take a closer look at the different concepts of knowledge underlying vaccination hesitancy.

Firstly, we present some background information on the history of vaccination hesitancy and opposition and we examine current studies in relation to this topic. Secondly, we report on select, empirical research into parental vaccination hesitancy that we carried out in 2014/2015. Finally, we argue that within the public discourse, vaccination hesitancy is too often equated with the anti-vaccine-movement and that it is useful to distinguish between vaccination hesitancy and vaccination opposition.

Vaccination Hesitancy - A Search for Traces

Vaccination hesitancy is as old as vaccinations themselves. In the 18th century fight against smallpox, Western Europe discovered variolation practices, that were already known in Asia and Africa. Therefore, even before Edward Jenner immunized the eight-year-old James Phipps with a serum of harmless cowpox in May 1796, proving the effectiveness of vaccination, the advantages and disadvantages of variolation were already being widely discussed across Europe. In France, Voltaire advocated variolation, while Jean Jacques Rousseau was far more hesitant (Zumbusch, 2014, p. 280). In his educational novel Emile, published in 1762, Rousseau does not deny the effectiveness of variolations, but he seems to suggest that nature-loving people do not need them at all (Rousseau, 1971, p. 118). The 18 th century discourse on variolation is closely linked with different motives of the Age of Enlightenment, such as the relationship between nature and culture or the relationship between the individual and society (Kopitzsch, 1998; Wirth, 2011; Zumbusch, 2014).

Similar to France and unlike England, there are longstanding reservations about vaccination in the Germanic countries. Although prominent educators of the enlightenment era commit themselves early on to the benefits 
of variolation (Basedow, 1777, p. 55; von Rochow, 1779, p. 53), there are some reports about opponents of variolation. The educator Paul Villaume, for example, stated that there is "much opposition" (Villaume, 1788, p. 122) towards variolations, either because one doubts their efficacy, or because one trusts in the underlying assumption that diseases are a "necessary crisis of nature" (Villaume, 1788, p. 122). Even after Edward Jenner discovered vaccination practices and cases of smallpox decreased over time, the arguments of opponents of vaccination changed very little. However, a new epidemiologic thinking led to calculations in relation to risk and security (Foucault, 2019, p. 91) and the German government introduced compulsory vaccination against smallpox in 1874. Yet, at the same time opponents of vaccination attempted to become more influential politically (Thießen, 2017, p. 32). It becomes obvious that vaccination is not just a medical issue, but a very political one. Early antivaccine initiatives legitimized themselves against different political backgrounds (Thießen, 2017, p. 32). Even the eradication of smallpox in 1979, regarded as one of the greatest medical achievements, does not silence the opponents of vaccination. It has also become clear that vaccination education can become a victim of its own success; precisely because vaccinations are successful, vaccine-preventable diseases disappear from public awareness. Until today the group of anti-vaccine campaigners has remained rather small but is nevertheless very visible in the public discourse.

Although opposition to vaccination has long been in existence, it has recently become a subject of scientific interest and certain efforts have been made to establish an overview of vaccination readiness in the various EU member states (European Commission, 2019) and even on a global scale (Larson et al., 2016). A vaccines advisory group to WHO has identified "complacency" (meant as risk perception), "inconvenience in accessing vaccines, and lack of confidence" as "key reasons underlying hesitancy" (WHO, 2019). Other concepts have been added in recent studies (Betsch et al., 2018). Research has been conducted into the "influence of vaccine-critical websites on perceiving vaccination risks" (Betsch et al., 2010) and especially on the information strategies aimed at parents (Benin et al., 2006). Such research regularly identifies that a broad spectrum of different attitudes towards vaccination should be taken into account: "common ground among these models is the fact that attitudes towards vaccination should be seen on a continuum ranging from active demand for vaccines to complete refusal of all vaccines" (Dubé et al., 2013). For example, the Eurobarometer 2019 states: "Nearly nine in ten $(85 \%)$ of the respondents think that vaccines are effective, with just a half (52\%) saying they are 'definitely' effective and a third (33\%) saying they are "probably' effective" (European Commission, 2019, p. 4). Just 3\% state that vaccines are not effective at all (European Commission, 2019 , p. 11). Therefore, only a very small proportion of those questioned are totally opposed to vaccination. In this respect, the distinction between vaccination hesitancy and vaccination opposition seems to be particularly relevant. Opponents of vaccination reject them on the basis of ideological, esoteric or religious reasons with great certainty (Meyer \& Reiter, 2004, p. 1185). In contrast, vaccination hesitancy does not necessarily mean that one is against vaccination but is casting doubt and suffers from a lack of confidence. Therefore, vaccination hesitancy, in a broader sense, seems more likely to be linked to uncertainty rather than certainty.

Impressions from Qualitative Research into Parental Vaccination Hesitancy

The very lack of confidence or trust and the suspiciousness of medical evidence, was the main focus of a qualitative microproject that we conducted at the MartinLuther-University, Halle-Wittenberg in 2014/15 (see J. O. Krüger \& Krüger, 2015; K. Krüger \& Krüger, 2015). We focused on parents who did not vaccinate their children. All six parents to whom we spoke were educated to a high standard and had been interviewed during or shortly after the last regional measles outbreak in Germany, in the year 2014. We soon became intrigued by the fact that although the parents we interviewed refused vaccination, they did not describe themselves as opponents of vaccination. On the contrary, they clearly distinguished themselves from radical vaccination opponents and conspiracy theorists and even explicitly recounted the advantages of vaccinations. One mother - we call her Yvette - told us:

I wouldn't call myself a vaccination opponent. I just want to decide for my kids. But I'm not dictating what's good for any other parent and their kids. I think it's important to gather knowledge, that enables me to make decisions consciously and not to do things just because it has always been like that. (Yvette)

Yvette emphasizes that her views against vaccination represent an individual case. She does not want her personal opinion to be understood as an expression of a general rejection of vaccination, but she demands knowledge. We found this argumentation pattern in all our interviews. Parents continuously complained about a lack of knowledge as the main reason for refusing vaccination. Another mother - we call her Henriette - stated that it is "mysterious what's in a vaccine": "You get a shot, you don't know what's in it, it's crazy".

Therefore, Henriette, as well as the other parents in our sample, maintained that she is continuously searching for more information on vaccines. She looks for information on the internet, she reads self-help literature and asks paediatricians for advice. However - as identified in our interviews - the search for information does not necessarily lead to more certainty on vaccination but can become a source of new uncertainty. Regine, a mother that studied pharmacy told us: 
"I generally know how vaccination works, and what it does in the body and so on. But this also leads me to questions that nobody can answer".

From Regine's perspective, certainty seems unattainable. In this situation, she reacts particularly sensitively when a doctor, with whom she discusses her uncertainty, treats her as a vaccination opponent, which she does not want to be. In summary, it can be said that the parents we interviewed argue from a problematic position. They do not reject vaccination, however, they want to take responsibility for their decision on vaccination, yet feel that the basis on which they justify their decision is not satisfactory.

\section{Conclusion}

The discourse on vaccinations identifies knowledge as being a problem (Schäfer \& Thompson, 2011, p. 22). Parents who are insecure about their children's vaccinations are not necessarily badly informed, but the information available does not seem sufficient to them. They hesitate because they think that they do not know enough. While the minority of those opposed to vaccination will perhaps not be reached by information campaigns, it can be assumed that the majority of vaccination-hesitant parents refuse vaccinations less on the basis of certainty than on the basis of uncertainty. This very feeling of uncertainty that a number of parents today are experiencing is akin to the discussions led by historical figures such as Rousseau. Regardless of the wealth of information (and opinions) today via internet databases and social media, information alone and the availability of information do not necessarily lead to more trust in vaccinations as a matter of course. Besides considering how to provide accessibility to information and publicizing "independent" information about vaccination, it would be beneficial to focus on how to promote trust.

We argue that, in a sample of parents with a high standard of education and access to a wealth of information, confidence in the effectivity and safety of vaccines and in the providing healthcare system is essential to increase the willingness to vaccinate. Further research could focus on the different social economic background and the ideological beliefs of parents who behave vaccination hesitant. Doubts about vaccinations may be related to a particular style of parenting (J. O. Krüger \& Krüger, 2015). Despite their vaccination hesitancy, these parents may be quite open to considering arguments in favour of vaccination (K. Krüger \& Krüger, 2015). Therefore, vaccination hesitancy should not be equated with the anti-vaccine movement.

\section{References}

Basedow, J. B. (1777). Practische Philosophie für alle Stände. Ein weltbürgerlich Buch ohne Anstoß für irgend eine Nation, Regierungsform und Kirche. Zweyter Theil. G. L. Crusius.

Bedford, H., Attwell, K., Danchin, M., Marshall, H., Corben, P., \& Leask, J. (2018). Vaccine hesitancy, refusal and access barriers: The need for clarity in terminology. Vaccine, 36(44), 6556-6558.

https://doi.org/10.1016/j.vaccine.2017.08.004

Benin, A. L., Wisler-Scher, D. J., Colson, E., Shapiro, E. D., \& Holmboe, E. S. (2006). Qualitative analysis of mothers' decision-making about vaccines for infants: The importance of trust. Pediatrics, 117(5), 1532-1541. https://doi.org/10.1542/peds.2005-1728

Betsch, C., Schmid, P., Heinemeier, D., Korn, L., Holtmann, C., \& Böhm, R. (2018). Beyond confidence: Development of a measure assessing the 5C psychological antecedents of vaccination. PLoS ONE, 13(12), e0208601. https://doi.org/10.1371/journal.pone.0208601

Betsch, C., Renkewitz, F., Betsch, T., \& Ulshöfer, C. (2010). The influence of vaccine-critical websites on perceiving vaccination risks. Journal of Health Psychology, 15(3), 446-455. https://doi.org/10.1177/1359105309353647

Dubé, E., Laberge, C., Guay, M., Bramadat, P., Roy, R., \& Bettinger, J. A. (2013). Vaccine hesitancy: An overview. Human Vaccines \& Immunotherapeutics, 9(8), 1763-1773. https://doi.org/10.4161/hv.24657

European Commission. (2019). Special Eurobarometer 488. Europeans' attitudes towards vaccination. Conducted by Kantar Public at the request of Directorate-General for Communication. Survey co-ordinated by the Directorate-General for Communication (DG COMM 'Media monitoring and Eurobarometer' Unit). Publications Office of the European Union. https://doi.org/10.2875/685461

Foucault, M. (2019). Sicherheit, Territorium, Bevölkerung. Geschichte der Gouvernementalität I. Suhrkamp.

Kopitzsch, F. (1998). Die Durchsetzung der Pockenimpfung. Zu Strategien und Mitteln aufgeklärter Reform in Hamburg und Schleswig-Holstein. In A. Conrad, A. Herzig, \& F. Kopitzsch (Eds.), Das Volk im Visier der Aufklärung. Studien zur Popularisierung der Aufklärung im späten 18. Jahrhundert (pp. 229-237). LIT. 
Krüger, J. O., \& Krüger, K. (2015). Skepsis im Entscheiden. Wie begründen impfskeptische Eltern ihre Impfentscheidungen? Zeitschrift für Qualitative Forschung, 16(1), 99-114. https://doi.org/10.3224/zqf.v16i1.22856

Krüger, K., \& Krüger, J. O. (2015). „Sich selber den Kopf zerbrechen“ - Eine qualitative Studie zu elterlicher Impfskepsis. Zeitschrift für Allgemeinmedizin, 91(3), 106-110. https://doi.org/10.3238/zfa.2015.0106-0110

Larson, H., de Figueiredo, A., Karafillakis, E., \& Rawal, M. (2018). State of vaccine confidence in the EU 2018. Publications Office of the European Union. https://doi.org/10.2875/241099

Larson, H. J., de Figueiredo, A., Xiahong, Z., Schulz, W. S., Verger, P., Johnston, I. G., Cook, A. R., \& Jones, N. S. (2016). The state of vaccine confidence 2016: Global insights through a 67-country survey. EBioMedicine, 12, $295-301$. https://doi.org/10.1016/j.ebiom.2016.08.042

Meyer, C., \& Reiter, S. (2004). Impfgegner und Impfskeptiker. Geschichte, Hintergründe, Thesen, Umgang. Bundesgesundheitsblatt - Gesundheitsforschung - Gesundheitsschutz, 47(12), 1182-1188. https://doi.org/10.1007/s00103-004-0953-x

Rochow, F. E. (1779). Der Kinderfreund. Ein Lesebuch zum Gebrauch in Landschulen. Zweyter Theil. Eichenbergschan Erben.

Rousseau, J. J. (1971). Emil oder Über die Erziehung. UTB.

Schäfer, A., \& Thompson, C. (2011). Wissen - eine Einleitung. In A. Schäfer \& C. Thompson (Eds.), Wissen (pp. 7-34). Ferdinand Schönigh.

Thießen, M. (2017). Immunisierte Gesellschaft. Impfen in Deutschland im 19. und 20. Jahrhundert. Vandenhoeck \& Ruprecht.

Villaume, P. (1788). Geschichte des Menschen. Zweyte Auflage. Siegfried Lebrecht Crusius.

World Health Organization. (2020). Vaccines and immunization. https:/www.who.int/topics/vaccines/en/

World Health Organization. (2019). Ten threats to global health in 2019. https://www.who.int/news-room/spotlight/tenthreats-to-global-health-in-2019

Wirth, U. (2011). Kultur als Pfropfung. Pfropfung als Kulturmodell. Prolegomena zu einer Allgemeinen Greffologie (2.0). In U. Wirth (Ed.), Impfen, Pfropfen, Transplantieren (pp. 9-28). Kadmos.

Zumbusch, C. (2014). Die Immunität der Klassik. Suhrkamp.

\title{
Recommended Citation
}

Krüger, J. O., \& Krüger, K. (2020). Vaccination hesitancy, knowledge and the role of confidence. On Education. Journal for Research and Debate, 3(8). https://doi.org/10.17899/on_ed.2020.8.5

\begin{abstract}
About the Authors
Jens Oliver Krüger is Professor for Education at the University of Koblenz, Germany. His current research focuses on parenthood, self-help-literature, school choice and philosophy of education. Together with Kathrin Krüger he conducted a qualitative microstudy on parental vaccination hesitancy in 2014 and 2015.
\end{abstract}

Kathrin Krüger is physician and works as a family doctor in Halle (Saale), Germany. Together with Jens Oliver Krüger she conducted a qualitative microstudy on parental vaccination hesitancy in 2014 and 2015. 